\title{
Eutrophication and its effect on dissolved Si concentrations in the Garonne River (France)
}

\author{
Koenraad MUYLAERT*, José Miguel SANCHEZ-PÉREZ1), Samuel TEISSIER ${ }^{1)}$, Sabine SAUVAGE ${ }^{1)}$, \\ Alain DAUTA ${ }^{1)}$ and Philippe VERVIER ${ }^{1)}$ \\ KULeuven Campus Kortrijk, Laboratory of Aquatic Biology, E. Sabbelaan 53, B-8500 Kortrijk, Belgium \\ ${ }^{1)}$ Laboratoire d'Ecologie Fonctionelle (EcoLab), UMR 5245 (CNRS-UPS-INPT), 29, rue Jeanne Marvig, 31055 Toulouse cedex, \\ France \\ *e-mail corresponding author: koenraad.muylaert@kuleuven-kortrijk.be
}

\begin{abstract}
Dissolved nutrient and chlorophyll-a concentrations were monitored on 17 occasions and at 16 sites in the Garonne River (France). Concentrations of dissolved inorganic nitrogen (DIN) and soluble reactive phosphorus (SRP) increased about threefold downstream of the urban area of Toulouse. Chlorophyll-a concentrations increased concomitantly with DIN and SRP downstream of Toulouse. Chlorophyll-a concentrations were maximal in late winter to early spring and in summer, in-between the snow-melt driven spring flood and rainfall-driven autumn flood. Dissolved silica (DSi) concentrations were negatively correlated with chlorophyll-a concentrations, suggesting uptake by algae. DSi depletion was more severe downstream of Toulouse, suggesting that eutrophication may affect DSi consumption in the Garonne River.
\end{abstract}

Key words: phytoplankton, diatoms, benthic biofilms, silica, eutrophication, Garonne River

\section{INTRODUCTION}

During the $20^{\text {th }}$ Century, $\mathrm{N}$ and $\mathrm{P}$ inputs into rivers around the world have increased dramatically as a result of intensive agriculture and industrial and municipal waste water discharges (Meybeck 1982). Increased concentrations of $\mathrm{N}$ and $\mathrm{P}$ are often accompanied by an increase in algal biomass or eutrophication. In rivers, the effects of eutrophication may be moderate because phytoplankton development is limited by short water retention times rather than inorganic nutrient concentrations. Nevertheless, many studies in different river basins have demonstrated a positive relation between $\mathrm{N}$ and $\mathrm{P}$ enrichment and algal biomass (e.g., Biggs \& Close 1989; Basu \& Pick 1996; Van Nieuwenhuyse \& Jones 1996; Lohman et al. 1999).

$\mathrm{N}$ and $\mathrm{P}$ have received much attention in eutrophication studies because they are essential nutrients for all phytoplankton groups and because their concentrations are strongly influenced by human activities. Si is only required by a few algal groups and $\mathrm{Si}$ concentrations are not directly influenced by human activities. Therefore, $\mathrm{Si}$ has historically received much less attention. The predominant source of dissolved silica (DSi) is the natural weathering of silicate minerals (Tréguer et al. 1995). The only significant human source of $\mathrm{Si}$ consists of metasilicates, of which small amounts are used in detergents and fertiliser. Nevertheless, recent estimates have shown that anthropogenic Si inputs may amount to 6\% of total Si inputs in a river basin (Sferratore et al. 2006). The most important algal group that requires $\mathrm{Si}$ are the diatoms, who need large amounts of Si for the construc- tion of their cell wall. Compared to other algal groups, diatoms are adapted to low-light conditions (because of the pigment fucoxanthin) and to a turbulent water column (because of their high cell density). Therefore, diatoms are often a dominant component of the phytoplankton of the turbulent and turbid lower reaches of rivers (e.g., Garnier et al. 1995). They are also important primary producers in the shallower, upper reaches of rivers, where they are a dominant component of the phytobenthos. Because of the importance of diatoms in river ecosystems, primary producers have a potentially strong influence on Si concentrations.

Due to anthropogenic inputs of $\mathrm{N}$ and $\mathrm{P}, \mathrm{Si}: \mathrm{N}$ and $\mathrm{Si}: \mathrm{P}$ ratio's have decreased in many rivers worldwide (Turner et al. 2003; Billen \& Garnier 2007). When Si:N and $\mathrm{Si}: \mathrm{P}$ ratio's are low, diatom production becomes limited by $\mathrm{Si}$ and total consumption of $\mathrm{Si}$ increases (Conley et al. 1993). Diatoms convert dissolved Si to biogenic Si or opal, which has a low remineralisation rate and easily accumulates in sediments. Therefore, $\mathrm{Si}$ consumption in rivers by diatoms may result in an increased retention of $\mathrm{Si}$ and a reduced export of $\mathrm{Si}$ to coastal ecosystems. Lower Si inputs in coastal waters have been shown to have an adverse effect on diatom production and to favour nuisance algae over diatoms (Humborg et al. 1997; Ittekkot et al. 2000; Cugier et al. 2005).

Most studies on $\mathrm{Si}$ retention in river basins have focused on retention of $\mathrm{Si}$ in lakes or reservoirs in river basins (e.g., Conley et al. 2000). These studies have shown that production of diatoms in reservoirs or lakes and subsequent burial of biogenic $\mathrm{Si}$ in sediments 


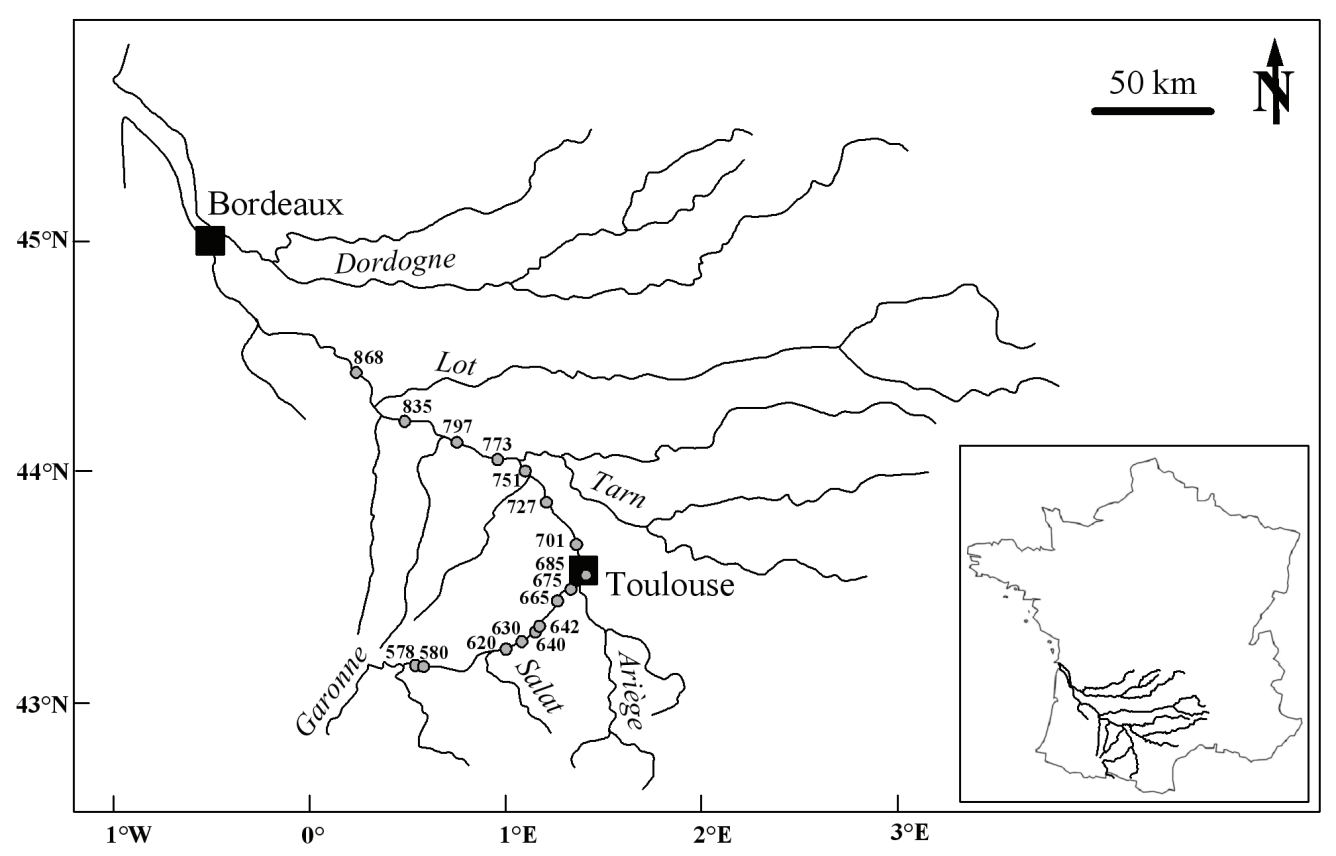

Fig. 1. Map of the Garonne River basin indicating the position of the sampling stations and the location of the major cities.

results in reduced dissolved Si transport to coastal systems (e.g., Conley et al. 2000; Humborg et al. 2000), although some of these claims have been refuted by more recent studies (Teodoru et al. 2006). Few studies have investigated the consequences of eutrophication on $\mathrm{Si}$ consumption in the river itself. Using an ecosystem model, Billen et al. (2001) demonstrated that increased anthropogenic $\mathrm{N}$ and $\mathrm{P}$ inputs resulted in increased retention of $\mathrm{Si}$ in the Seine River basin over the last 50 years. Here we present monitoring data from the Garonne River that suggest that $\mathrm{N}$ and $\mathrm{P}$ inputs from the city of Toulouse result in increased consumption of dissolved Si by algae.

\section{METHODS}

With a catchment of $57,000 \mathrm{~km}^{2}$, the Garonne River basin is the third largest river basin in France after the Rhone and Seine (Fig. 1). The Garonne River is a shallow river (generally $<2 \mathrm{~m}$ ) and has a high flow velocity, even in its lower reaches $\left(\sim 0.4 \mathrm{~m} \mathrm{~s}^{-1}\right)$. This high flow velocity prevents planktonic algae to attain a high biomass (Améziane et al. 2003). Due to an important fraction of hard substrates in the river bed, turbidity of the Garonne River is low compared to other lowland rivers, with suspended matter concentrations usually being below $50 \mathrm{mg} \mathrm{L}^{-1}$ (Coynel et al. 2004). This low turbidity combined with a shallow depth allows diatom biofilms to develop on the river bed (Eulin \& Le Cohu 1998; Teissier et al. 2002; Améziane et al. 2003; Boulêtreau et al. 2006). Diatom biofilms regularly detach when their biomass is high and are then mixed into the water column (Bouletreau et al. 2006). Diatoms from these biofilms make up about half of the cell numbers in phytoplankton samples of the Garonne River (Améziane et al. 2003). Both planktonic and biofilm diatoms may consume $\mathrm{Si}$ in the Garonne River.

The catchment of the Garonne River is predominantly agricultural and contains only one major urban area, Toulouse. The urban area of Toulouse is situated at the confluence of the Garonne and Ariège rivers and has approximately 1 million inhabitants. The largest tributary of the Garonne River downstream of Toulouse is the Tarn River. In contrast to the Garonne River, the Tarn River has no major urban areas in its catchment. The reservoir of Malause is situated at the confluence of the Garonne and Tarn rivers. The Malause reservoir is a large reservoir with a relatively shallow depth (area: 420 ha, mean depth: $3.6 \mathrm{~m}$ ).

The main goal of this study was to evaluate eutrophication caused by the urban area of Toulouse and the resulting impact on dissolved Si concentrations. Water samples were collected at 16 sites upstream and downstream of the city of Toulouse on 17 occasions between July 1992 to September 1993. Sampling occasions were selected to cover high-discharge as well as low-discharge periods. Water was collected using a bucket from bridges or from the river bank, as close as possible to the centre of the main channel. Temperature was measured in the field using a WTW 96 probe. For determination of chlorophyll- $a$ concentration, a known volume of water was filtered through a $\mathrm{GF} / \mathrm{C}$ filter. Chlorophyll- $a$ was extracted in boiling ethyl alcohol and quantified spectrophotometrically (Marker et al. 1980). For determination of dissolved nutrients, water was filtered through GF/F filters and stored at $4{ }^{\circ} \mathrm{C}$ until analysis (within 48 hours). Nitrate, nitrite and silica concentrations were measured with a Technicon autoanalyser. Nitrite was determined using the diazotation method, 


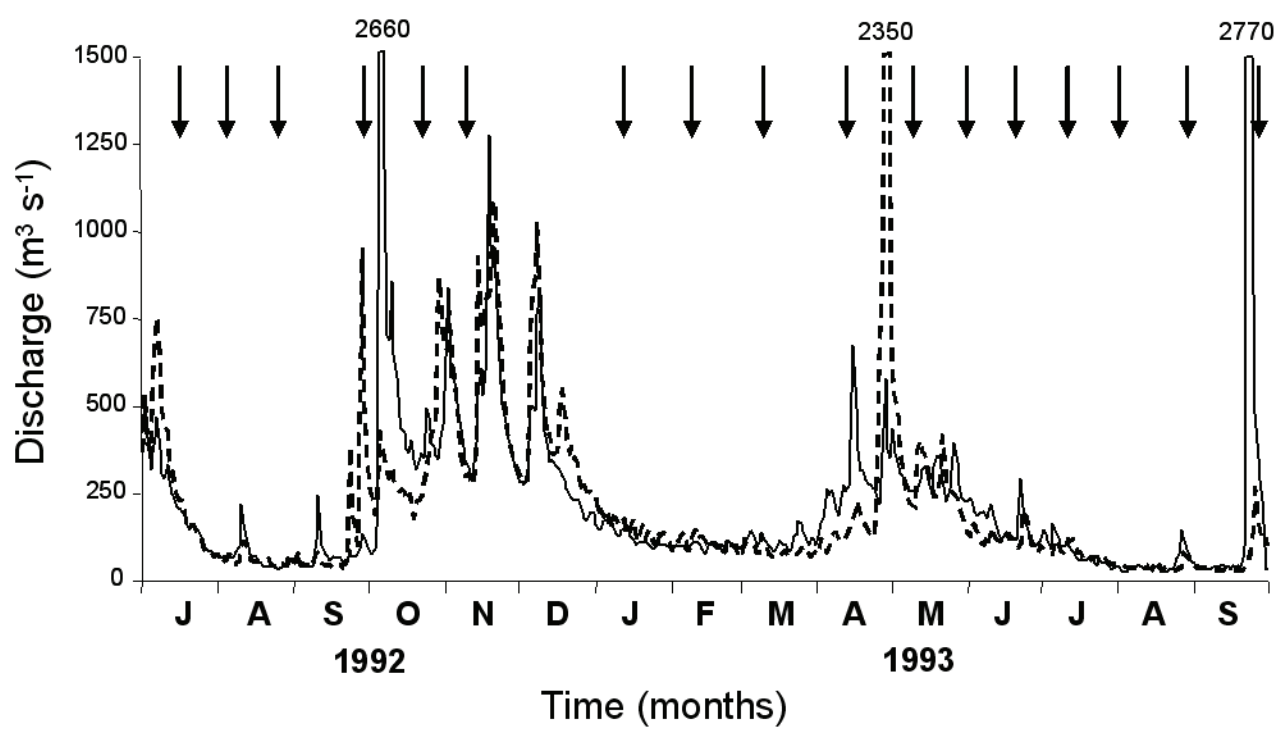

Fig. 2. Discharge of the Garonne (solid line) and Tarn (dotted line) rivers just upstream of their confluence in the Malause Reservoir Garonne confluence during the study period. The vertical arrows indicate the times when samples were collected.
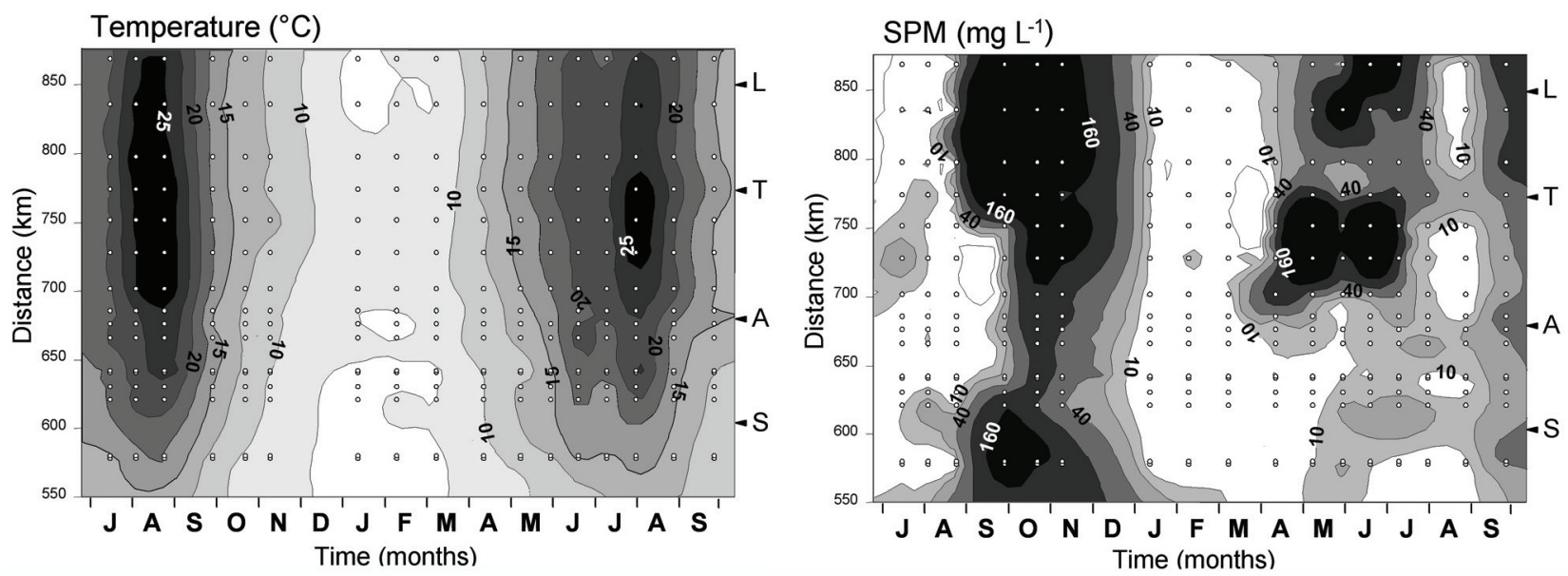

Fig. 3. Spatiotemporal variability of temperature and SPM concentrations in the Garonne River. Variation along the longitudinal gradient of the Garonne is represented along the vertical axis (from upstream below to downstream above). The position of the major tributaries is indicated on the right (S: Salat, A: Ariège, T: Tarn and L: Lot). The temporal variation is indicated on the horizontal axis. Sampling occasions/locations are indicated as white points in the contour map.

nitrate was determined by cadmium reduction into nitrite and dissolved silica (DSi) was determined by the ammonium molybdate method (APHA 1985). Ammonium was measured spectrophotometrically by the indophenol blue method according to Scheiner (1976). Soluble reactive phosphorus (SRP) was determined spectrophotometrically with the molybdate and malachite green method (Motomizu et al. 1983). Dissolved inorganic nitrogen (DIN) was calculated as the sum of ammonium, nitrate and nitrite. Determination of solid particulate matter (SPM) concentrations was performed by filtration using dry pre-weighed filters (Whatman GF/F, $0.7 \mu \mathrm{m}$ ). Daily discharge data for the Garonne (at Verdun) and Tarn (at Moissac) rivers were provided by water authorities (DIREN Midi-Pyrenees and CA des Coteaux de Gascogne HYDRO-MEDD/DE).

\section{RESULTS}

Discharge of the Garonne and Tarn rivers upstream of their confluence in the Malause reservoir is shown in figure 2. The Garonne River had a high discharge in late autumn to early winter as well as in spring. Discharge of the Tarn River was comparable to that of the Garonne River in summer and autumn but it was slightly higher than that of the Garonne River in winter and lower in spring. In winter, temperature was below $10{ }^{\circ} \mathrm{C}$ throughout the river section under investigation (Fig. 3). In summer, temperature was below $18{ }^{\circ} \mathrm{C}$ at the most upstream station sampled but increased up to $28{ }^{\circ} \mathrm{C}$ downstream of the confluence of the Garonne and Ariège rivers. SPM concentrations were generally low $\left(<40 \mathrm{mg} \mathrm{L}^{-1}\right)$ during the low flow periods in winter to 

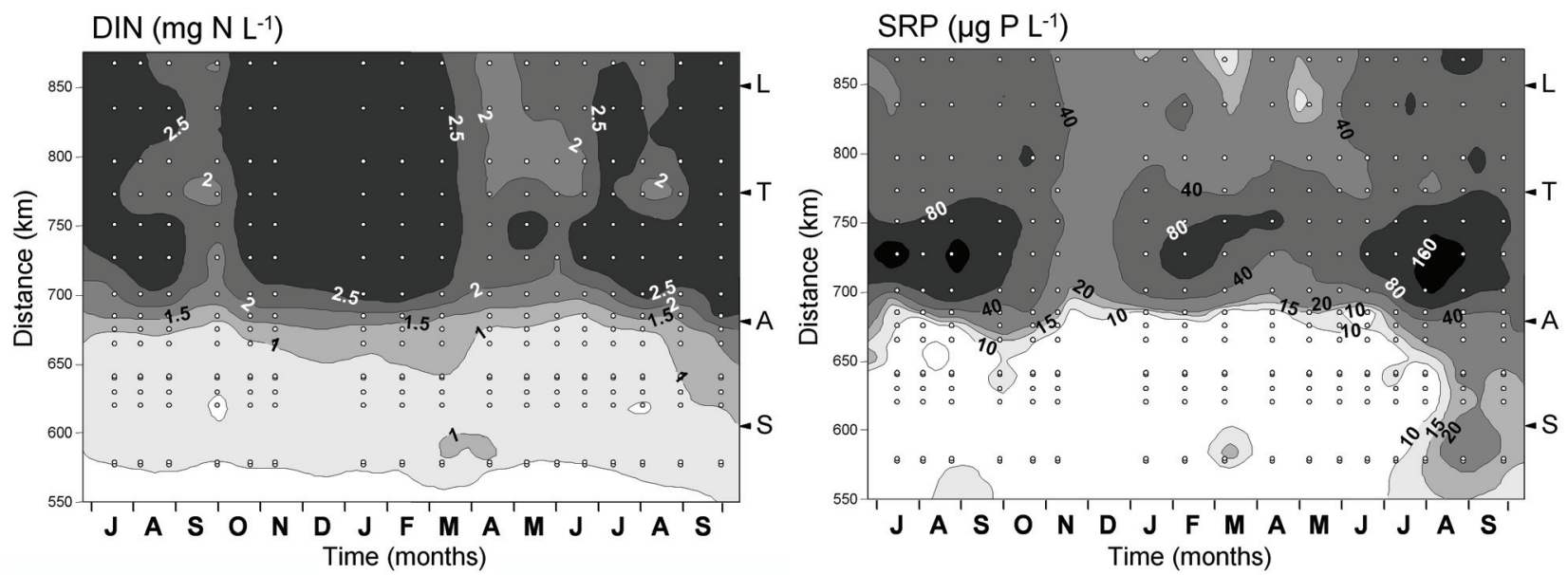

Fig. 4. Spatiotemporal variability of DIN and SRP concentrations in the Garonne River. Variation along the longitudinal gradient of the Garonne is represented along the vertical axis (from upstream below to downstream above). The position of the major tributaries is indicated on the right (S: Salat, A: Ariège, T: Tarn and L: Lot). The temporal variation is indicated on the horizontal axis. Sampling occasions/locations are indicated as white points in the contour map.
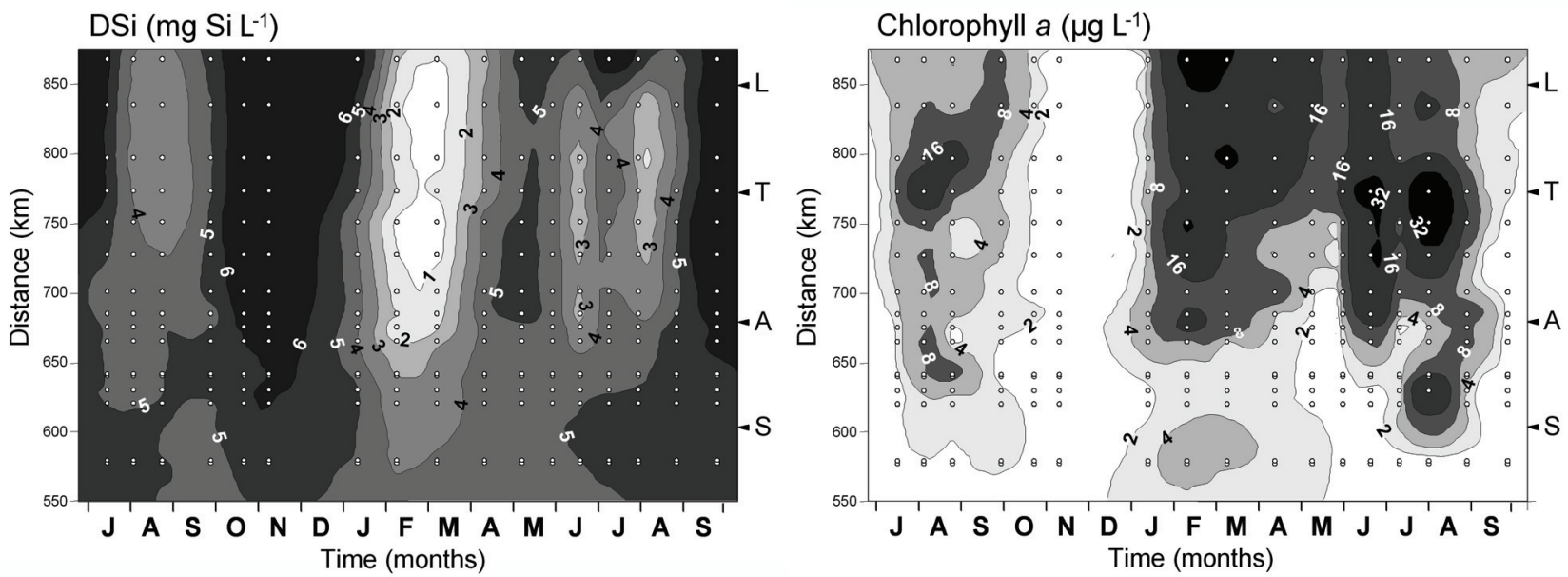

Fig. 5. Spatiotemporal variability of DSi and chlorophyll- $a$ concentrations in the Garonne River. Variation along the longitudinal gradient of the Garonne is represented along the vertical axis (from upstream below to downstream above). The position of the major tributaries is indicated on the right (S: Salat, A: Ariège, T: Tarn and L: Lot). The temporal variation is indicated on the horizontal axis. Sampling occasions/locations are indicated as white points in the contour map.

early spring and summer (Fig. 3). Peaks in SPM concentrations were observed during the autumn floods along the entire river section and in late spring in the section downstream of the confluence of the Tarn with the Garonne River.

DIN concentrations increased from $<1 \mathrm{mg} \mathrm{L}^{-1}$ upstream of Toulouse to $>2 \mathrm{mg} \mathrm{L}^{-1}$ downstream of Toulouse (Fig. 4) and concentrations were lower during high discharge periods in winter. SRP concentrations were usually $<10 \mu \mathrm{g} \mathrm{L}^{-1}$ upstream of Toulouse (Fig. 4). Only in late summer 1993, higher SRP were measured upstream of Toulouse. Downstream of Toulouse, SRP increased to $>20 \mu \mathrm{g} \mathrm{L}^{-1}$. Downstream of the confluence between the Tarn and Garonne rivers, SRP decreased again by about $50 \%$. DIN and SRP concentrations displayed little seasonal variability upstream of Toulouse. Downstream of Toulouse, lower DIN concentrations were measured in late summer 1992 and spring 1993 while SRP concentrations displayed a decline in autumn 1992 and spring 1993. DSi concentrations displayed more seasonal variation than spatial variation (Fig. 5). Highest DSi concentrations were measured in autumn to winter 1992 and 1993 (5-6 $\left.\mathrm{mg} \mathrm{L}^{-1}\right)$ and in spring 1993 (4-5 $\mathrm{mg} \mathrm{L}^{-1}$ ). During these periods, DSi increased slightly in downstream direction. Seasonal declines in DSi concentrations were observed in summer 1992 and $1993\left(<4 \mathrm{mg} \mathrm{L}^{-1}\right)$ and in late winter - early spring 1993 $\left(<1 \mathrm{mg} \mathrm{L}^{-1}\right)$. These seasonal declines in DSi were more pronounced downstream than upstream of Toulouse.

Elevated chlorophyll- $a$ concentrations were measured in summer 1992 and 1993 and in late winter early spring 1993 (Fig. 5). These increases in chlorophyll a concentration were more pronounced at the downstream than at the upstream sites. Chlorophyll-a 
concentrations always exceeded $16 \mu \mathrm{g} \mathrm{L}^{-1}$ during these blooms, with the maximum concentration measured being $67 \mu \mathrm{g} \mathrm{L}^{-1}$ (in the Malause Reservoir). In autumn 1992 and 1993, chlorophyll- $a$ concentration was $<2 \mu \mathrm{g}$ $\mathrm{L}^{-1}$. Chlorophyll- $a$ concentrations were significantly positively correlated with DIN and SRP concentrations (Pearson correlation coefficients 0.42 for DIN and 0.28 for SRP, $\mathrm{n}=270$, both $p<0.0001$, Fig. 6). A negative correlation was observed between chlorophyll- $a$ and DSi (Pearson correlation coefficient $-0.66, \mathrm{n}=270, p$ $<0.0001$, Fig. 6).
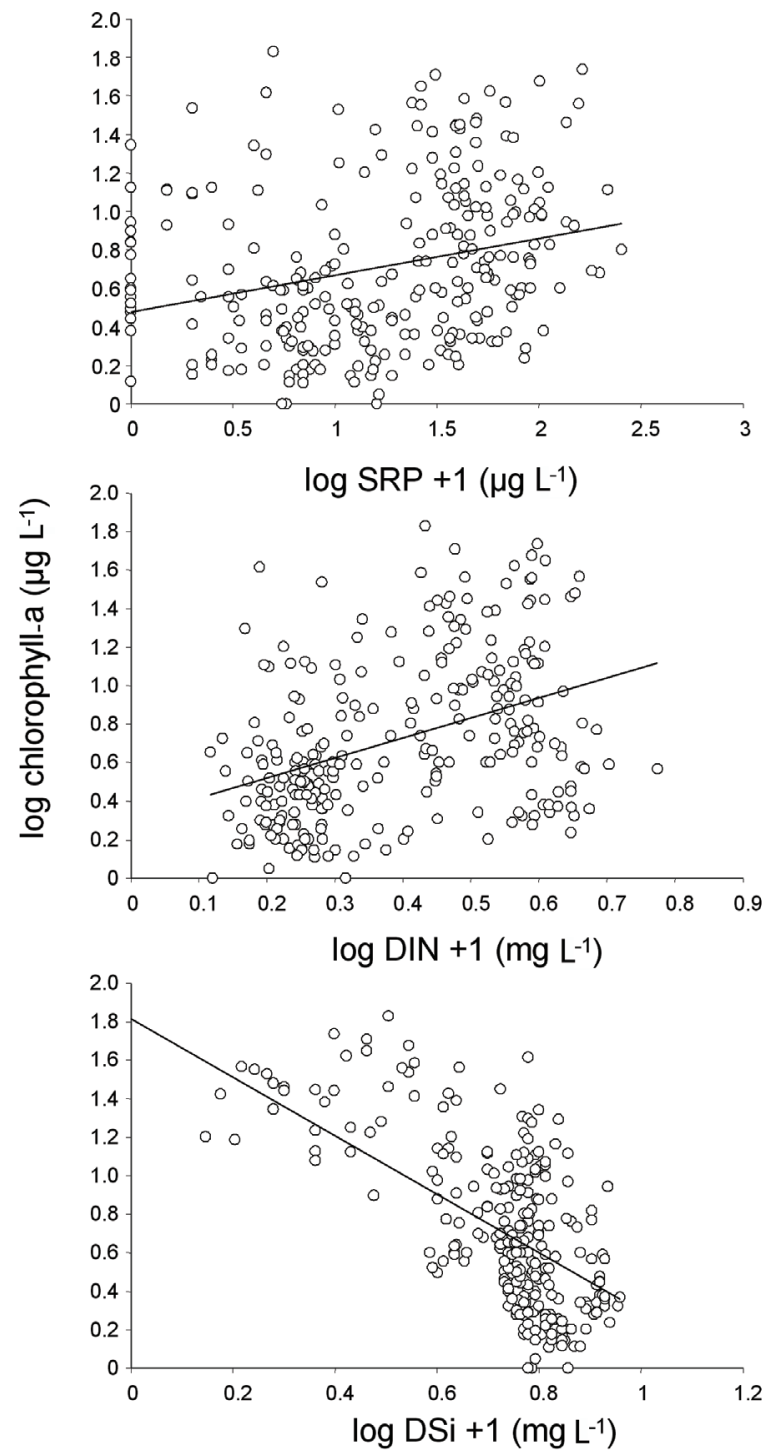

Fig. 6. Correlation of chlorophyll a concentration with concentrations of SRP, DIN and DSi in the Garonne River.

\section{DISCUSSION}

DIN and SRP concentrations more than doubled downstream of the urban area of Toulouse. Upstream of Toulouse, SRP concentrations were below $10 \mu \mathrm{g} \mathrm{L}^{-1}$, which corresponds to oligotrophic conditions (Wetzel
2001). Downstream of Toulouse, SRP concentrations exceeded $40 \mu \mathrm{L}^{-1}$ for most of the year, which corresponds to eutrophic conditions. The increase in DIN and SRP concentrations can probably be ascribed to intensive agriculture and waste discharges in the Toulouse urban area. In contrast, DSi concentrations did not increase downstream of the Toulouse urban area. The data presented here are the first published data demonstrating eutrophication of the Garonne River by the city of Toulouse. It should be noted that the data used in this study are relatively old and that the situation most likely has improved since these data were collected (cf. Tudesque et al. 2007).

SRP and, to a lesser extent, DIN decreased during periods of high discharge in autumn 1992 and in late spring 1993. This phenomenon can probably be ascribed to dilution of nutrient inputs derived from point sources. SRP also decreased downstream of the confluence of the Garonne and Tarn rivers. This can be ascribed to dilution of P-rich water from the Garonne River by relatively P-poor water of the Tarn River. In contrast to the Garonne, the Tarn River has no major cities in its basin. The Malause Reservoir probably contributed to the decline in SRP downstream of the confluence of the Garonne and Tarn rivers. The Malause Reservoir possesses a dense vegetation of submerged macrophytes that consumes a significant part of the SRP supplied by the Garonne River (M. Sow, unpublished results).

Elevated chlorophyll- $a$ concentrations were observed in summer 1992, in late winter to early spring 1993 and in summer 1993. The periods of elevated chlorophyll- $a$ concentration occurred when discharge was low. Due to the fluvio-nival discharge regime of the Garonne River, low-discharge periods occurred not only in summer but also in late winter to early spring, inbetween the rain-driven autumn floods and the snowmelt-driven spring floods. The chlorophyll- $a$ measured in the water column was probably derived from both planktonic algae and detached algal biofilms (Améziane et al. 2003). Planktonic as well as benthic algae both develop during low-discharge periods. Phytoplankton suffers fewer losses due to downstream displacement during periods of low discharge. Therefore an inverse relation between discharge and chlorophyll- $a$ is often observed in rivers (Reynolds \& Descy 1996). Benthic algal biofilms are eroded during flood events and therefore tend to have higher biomass during prolonged low discharge periods in rivers (Biggs \& Close 1989; Lohman et al. 1999). Biomass of phytoplankton as well as benthic algal biofilms has been found to be maximal during periods of low discharge in previous studies in the Garonne River (Améziane et al. 2003; Boulêtreau et al. 2006).

During the low-discharge periods, chlorophyll- $a$ concentrations were higher downstream than upstream of the urban area of Toulouse. The significant positive relationship between chlorophyll- $a$ and DIN and SRP 
concentrations suggests that eutrophication by the urban area of Toulouse stimulated algal development in the Garonne River. In rivers, eutrophication results in a higher biomass of planktonic algae (Basu \& Pick 1996; Van Nieuwenhuyse \& Jones 1996) as well as benthic biofilm algae (Biggs \& Close 1989). Seasonal increases in chlorophyll- $a$ concentration had no impact on concentrations of DIN and SRP.

As opposed to $\mathrm{N}$ and $\mathrm{P}$, DSi declined strongly when discharge was low and chlorophyll- $a$ concentrations were high. DSi concentrations were strongly inversely correlated with chlorophyll- $a$. As diatoms are a major component of both planktonic and benthic algal communities in the Garonne River (Eulin \& Le Cohu 1998; Améziane et al. 2003), the inverse relation between chlorophyll- $a$ and DSi can be ascribed to DSi consumption by diatoms. Depletion of DSi by planktonic diatoms is common in lowland rivers (e.g., Admiraal et al. 1993). Depletion of DSi by diatom biofilms has also been reported from rivers (Casey et al. 1981; House et al. 2001). DSi concentrations never dropped below 0.4 $\mathrm{mg} \mathrm{L}^{-1}$, which is well above the limiting levels for diatom uptake of Si (about $0.1 \mathrm{mg} \mathrm{L}^{-1}$, Martin-Jézequel et al. 2000). Therefore, although diatoms depleted DSi in the Garonne River, they probably never did so to a level that their growth became limited by $\mathrm{Si}$.

Depletion of DSi was most pronounced downstream of the city of Toulouse, where chlorophyll- $a$ concentrations were higher due to elevated levels of DIN and SRP associated with the city of Toulouse. This suggests that depletion of DSi in the Garonne basin was stimulated by eutrophication by the city of Toulouse. Semhi et al. (2000) studied weathering of silicate minerals in the Garonne catchment and also observed a positive correlation between discharge and DSi in the Garonne River. They ascribed this to removal of solutes from soils by percolating water during high flow periods. Although this process may partly explain temporal variations in dissolved $\mathrm{Si}$ concentrations in the Garonne River, the decline in DSi concentrations below Toulouse and the concomitant increase of chlorophyll- $a$ concentrations suggests a biological mechanism behind the seasonal changes in DSi concentrations.

Our data illustrate that inputs of $\mathrm{N}$ and $\mathrm{P}$ in rivers may result in an increase in DSi consumption by diatoms. As DSi is converted into biogenic Si and as biogenic $\mathrm{Si}$ has a low remineralisation rate, this may result in a decrease in Si fluxes to coastal waters. Unfortunately, the lack of biogenic Si data and dissolved Si data from tributaries prevented calculating a mass-balance for Si to estimate total Si retention on an annual timescale.

\section{REFERENCES}

Admiraal, W., S.D. Mylius, E.D. De Ruyter-Van Steveninck \& D.M.J. Tubbing. 1993. A model of phytoplankton production in the lower River Rhine verified by observed changes in silicate concentration. J. Plankton Res., 15: 659-682.

Améziane, T., A. Dauta \& R. Le Cohu. 2003. Origin and transport of phytoplankton in a large river: the Garonne, France. Archiv. Hydrobiol., 156: 385-404.

APHA. 1985. Standard methods for the examination of water and wastewater. $16^{\text {th }}$ ed. American Public Health Association.

Basu, B.K. \& F.R. Pick. 1996. Factors regulating phytoplankton and zooplankton biomass in temperate rivers. Limnol. Oceanogr., 41: 1572-1577.

Biggs, B.J.F. \& M.E. Close. 1989. Periphyton biomass dynamics in gravel bed rivers - the relative effects of flows and nutrients. Freshwat. Biol., 22: 209-231.

Billen, G. \& J. Garnier. 2007. River basin nutrient delivery to the coastal sea: assessing its potential to sustain new production of non-siliceous algae. Mar. Chem., 106: 148-160.

Billen, G., J. Garnier, A. Ficht \& C. Cun. 2001. Modelling the response of water quality in the Seine River estuary to human activity in its watershed over the last 50 years. Estuaries, 24: 977-993.

Boulêtreau S., F. Garabetian, S. Sauvage \& J.-M. SanchezPerez. 2006. Assessing the importance of a self-generated detachment process in river biofilm models. Freshwat. Biol., 51: 901-912.

Casey, H., R.T. Clarke \& A.F.H. Marker. 1981. The seasonalvariation in silicon concentration in chalk-streams in relation to diatom growth. Freshwat. Biol., 11: 335-344.

Conley, D.J., P. Stålnacke, H. Pitkänen \& A. Wilander. 2000. The transport and retention of dissolved silicate by rivers in Sweden and Finland. Limnol. Oceanogr., 45: 18501853.

Conley, D.L., C. Schelske \& E.F. Stoermer. 1993. Modification of the biogeochemical cycle of silica with eutrophication. Mar. Ecol. Progr. Ser., 101: 179-192.

Coynel, A., J. Schäfer, J.E. Hurtrez, J. Dumas, H. Etcheber \& G. Blanc. 2004. Sampling frequency and accuracy of SPM flux estimates in two contrasted drainage basins. Sc.Total Envir., 330: 233-247.

Cugier, P., G. Billen, J.F. Guillaud, J. Garnier \& A. Menesguen. 2005. Modelling the eutrophication of the Seine Bight (France) under historical, present and future riverine nutrient loading. J. Hydrol., 304: 381-396.

Eulin, A. \& R. Le Cohu. 1998. Epilithic diatom communities during the colonization of artificial substrates in the river Garonne (France): comparison with the natural communities. Arch. Hydrobiol., 143: 79-106.

Garnier, J., B. Leporcq, N. Sanchez \& X. Philippon. 1999. Biogeochemical mass balances $(\mathrm{C}, \mathrm{N}, \mathrm{P}, \mathrm{Si})$ in three large reservoirs of the Seine basin (France). Biogeochemistry, 47: 119146.

House, W.A., D.V. Leach \& P.D. Armitage. 2001. Study of dissolved silicon and nitrate dynamics in a freshwater stream. Wat. Res., 35: 2749-2757.

Humborg, C., D.J. Conley, L. Rahm, F. Wulff, A. Cociasu \& V. Ittekot. 2000. Silica retention in river basins: far reaching effects on biogeochemistry and aquatic food aquatic food webs. Ambio, 29: 45-50.

Humborg, C., V. Ittekot, A. Cociasu \& B. von Bodungen. 1997. Effect of Danube river dam on Black Sea biogeochemistry and ecosystem structure. Nature, 386: 385-388.

Ittekkot, V., C. Humborg \& P. Schäfer. 2000. Hydrological alterations and marine biogeochemistry: a silicate issue? BioScience, 50: 776-782.

Lohman, K., J.R. Jones \& B.D. Perkins. 1992. Effects of nutrient enrichment and flood frequency on periphyton biomass in northern Ozark streams. Can. J. Fish. Aquat. Sci., 49: 1198-1205.

Marker, A.F.H., E.A. Nusch, H. Rai \& B. Reimann. 1980. The measurements of photosynthetic pigments in freshwater and standardization of methods. Ergebn. Limnol., 14: 91-106. 
Martin-Jézéquel, V., M. Hildebrand \& M.A. Brzezinski. 2000. Silicon metabolism in diatoms: implications for growth. $J$. Phycol., 36: 821-840.

Meybeck, M. 1982. Carbon, nitrogen, and phosphorus transport by world rivers. Am. J. Sci., 282: 401-450.

Motomizu, S., T. Wakimoto \& S. Toei. 1983. Spectrophotometric determination of phosphate in river waters with molybdate and malachite green. Analyst, 118: 361-367.

Reynolds, C.S. \& J.-P. Descy. 1996. The production, biomass and structure of phytoplankton in large rivers. Arch. Hydrobiol. Beih., 113: 161-187.

Scheiner, D. 1976. Determination of ammonia and Kjeldhal nitrogen by indophenol method. Wat. Res., 10: 31-36.

Semhi, K., P. Amiotte Suchet, N. Clauer \& J.-L. Probst. 2000. Dissolved silica in the Garonne River waters: changes in the weathering dynamics. Envir. Geol., 40: 19-26.

Sferratore, A., J. Garnier, G. Billen, D.J. Conley \& S. Pinault. 2006. Diffuse and point sources of silica in the seine river watershed. Envir. Sci. \& Technol., 40: 6630-6635.

Teissier, S., F. Garabetian, M. Torre, D. Dalger \& L. Labroue. 2002. Impact of an urban centre on the nitrogen cycle processes of epilithic biofilms during a summer low-water period. River Res. Appl., 18: 21-30.

Received: December 2008

Accepted: June 2009
Teodoru, C., A. Dimopoulos \& B. Wehrli. 2006. Biogenic silica accumulation in the sediments of Iron Gate I reservoir on the Danube River. Aquat. Sci., 68: 469-481.

Tréguer, T., D.M. Nelson, A.J. Van Bennekom, D. Demaster, A. Leynaert \& B. Quéguiner. 1995. The silica balance in the world ocean: a reestimate. Science, 286: 375-379.

Tudesque, L., M. Gevrey, G. Grenouillet \& S. Lek. 2008. Long-term changes in water physicochemistry in the Adour-Garonne hydrographic network during the last three decades. Wat. Res., 42: 732-742.

Turner, R.E., N.N. Rabalais, D. Justic \& Q. Dortch. 2003. Global patterns of dissolved N, P and $\mathrm{Si}$ in large rivers. Biogeochemistry, 64: 297-317.

Van Nieuwenhuyse, E.E. \& J.R. Jones. 1996. Phosphoruschlorophyll relationship in temperate streams and its variation with stream catchment area. Can. J. Fish. Aquat. Sci., 53: 99-105.

Wehr, J.D. \& J.-P. Descy. 1998. Use of phytoplankton in large river management. J. Phycol., 34: 741-749.

Wetzel, R.G. 2001. Limnology: lake and river ecosystems. $3^{\text {rd }}$ ed. Academic Press, San Diego. 